\title{
Sistem Pencarian Informasi Berbasis Ontologi untuk Jalur Pendakian Gunung Menggunakan Query Bahasa Alami dengan Penyajian Peta Interaktif
}

\author{
Fadhila Tangguh Admojo*1, Edi Winarko ${ }^{2}$ \\ ${ }^{1}$ Prodi S2/S3 Ilmu Komputer, FMIPA UGM, Yogyakarta \\ ${ }^{2}$ Jurusan Ilmu Komputer dan Elektronika, FMIPA UGM, Yogyakarta \\ e-mail: $*^{1}$ fadhila.tangguh@gmail.com, $\underline{\text { ewinarko@ugm.ac.id }}$
}

\begin{abstract}
Abstrak
Informasi jalur pendakian gunung telah banyak tersedia di internet. Namun, untuk mendapatkan informasi yang sesuai dengan kebutuhan, membutuhkan waktu untuk menelusuri dan membandingkan setiap informasi yang tersedia. Beragamnya konten hasil pencarian justru membingungkan para pendaki.

Penelitian ini bertujuan untuk memberikan solusi dari permasalahan yang dihadapi pendaki dengan mengembangkan sebuah sistem pencarian informasi jalur pendakian gunung menggunakan pendekatan berbasis teknologi semantik (ontologi).

Sistem dikembangkan menggunakan dua basis pengetahuan (ontologi), yaitu: ontologi Bahasa sebagai representasi pengetahuan linguistik dan ontologi Mountaineering sebagai representasi pengetahuan jalur pendakian dan gunung. Sistem dirancang untuk memproses dan memahami input berupa bahasa alami. Proses pemahaman bahasa alami didasarkan pada analisis sintaksis dan semantik dengan menggunakan aturan-aturan tata bahasa Indonesia. Proses pencarian informasi dilakukan berdasarkan hasil pemahaman dan informasi yang disajikan kepada pengguna dilengkapi dengan peta interaktif.

Hasil penelitian yang dilakukan menunjukkan bahwa sistem yang dikembangkan mampu memahami input bahasa alami pencarian dan mampu mendeteksi input yang tidak sesuai dengan kaidah tata bahasa Indonesia baik secara sintaksis maupun secara semantik. Sistem juga mampu menggunakan thesaurus kata dalam melakukan proses pencarian. Berdasarkan hasil pengujian kuantitatif sistem dapat memahami input yang diambil secara acak dari responden sebesar $69 \%$.
\end{abstract}

Kata kunci-Ontologi, NLP, Parsing, Analisis sintaksis dan semantik

\begin{abstract}
Mountain climbing path information has been widely available on the internet. However, to get information that suits the needs of climbers take time to browse and compare all the available information. The diversity of the search results content actually confuse the climbers.

This research aims to provide a solution to the problems faced by climbers, by developing an information retrieval system for mountain climbing path using semantic technology (ontology) based approach .

The system is developed by using two knowledge base (ontology), ontology Bahasa represents linguistic knowledge and ontology Mountaineering represents mountaineering knowledge. The system is designed to process and understand natural language input form. The process of understanding the natural language based on syntactic and semantic analysis using the rules of Indonesian grammar.
\end{abstract}


The results of the research that has been conducted shows that the system is able to understand natural language input and is capable of detecting input that is not in accordance with the rules of Indonesian grammar both syntactically and semantically. The system is also able to use a thesaurus of words in the search process. Quantitative test results show that the system is able to understand $69 \%$ of inputs are taken at random from the respondents.

Keywords - Information retrieval, Ontologies, NLP, Parsing, Syntactic and semantic Analysis

\section{PENDAHULUAN}

\subsection{Latar Belakang}

Kekayaan alam pegunungan yang dimiliki Indonesia mendorong tumbuh berkembangnya olahraga mendaki gunung (mountain climbing). Mengumpulkan informasi sebanyak mungkin mengenai daerah atau lokasi (gunung) sebelum melakukan pendakian menjadi hal yang penting agar dapat mempersiapkan jadwal, perlengkapan dan perbekalan yang dibutuhkan, karena kegiatan di alam bebas (mendaki gunung) dapat berjalan dengan lancar tergantung bagaimana pelakunya mempersiapkan diri [1].

Penyebab utama banyaknya kasus pendaki yang tersesat dan hilang di gunung dikarenakan kurangnya informasi tentang jalur dan medan pendakian. Informasi jalur dan medan pendakian merupakan informasi yang paling vital dalam suatu pendakian. Sulitnya mendapatkan literatur dalam bentuk buku mengenai informasi pendakian gunung-gunung di Indonesia, menjadikan internet sebagai media utama dalam mengumpulkan informasi pendakian. Melakukan pencarian informasi pendakian gunung yang spesifik di Internet memunculkan suatu permasalah baru dikalangan pendaki, yaitu : hasil pencarian yang banyak dan beragam sehingga membutuhkan waktu lebih banyak untuk menelusuri dan membandingkan setiap informasi, banyaknya konten informasi yang tersedia justru membingungkan pendaki.

Penelitian [2] berupaya menyediakan solusi dari masalah yang dihadapi pendaki dengan mengembangkan suatu sistem informasi pemandu pendakian yang dapat menyajikan informasi jalur pendakian gunung dalam bentuk teks dan gambar. Akan tetapi sistem yang telah dikembangkan [2] belum mampu menjawab permasalahan yang dihadapi pendaki untuk mendapatkan informasi yang tepat dalam waktu yang singkat. Sistem [2] tidak menyediakan fungsi pencarian sehingga pengguna tidak dapat berinteraksi dengan sistem mengenai informasi yang diinginkan. Pengguna masih harus mencari informasi secara manual kedalam konten informasi yang disajikan.

Sehubungan dengan kelemahan pada penelitian [2], penelitian [3] memaparkan bahwa kendala menggunakan pendekatan model data relasional adalah kurang dinamis untuk mendukung penyimpanan informasi yang lebih bermakna secara semantik, sehingga untuk melakukan pencarian dengan berbagai variasi pengetahuan terhadap data akan menjadi sangat terbatas. Dengan menggunakan basis pengetahuan teknologi semantik (ontologi), model data yang digunakan untuk kasus-kasus pencarian informasi dapat dideskripsikan secara lebih semantik dan dapat digunakan berdasarkan persepsi pengguna. [4] memaparkan pencarian dengan basis semantik berarti melakukan pencarian informasi berdasarkan makna yang terkait dengan kata kunci penelusuran, pencarian semantik adalah mencari konten yang sesuai dengan konteks yang diinginkan pengguna.

Penelitian tentang pencarian semantik dengan input berupa bahasa alami pernah dilakukan oleh [5], [6], [7] dan [8]. Meskipun keempat penelitian tersebut menggunakan ontologi dengan pendekatan yang berbeda-beda, dari hasil penelitian dapat dikatakan bahwa penggunaan ontologi mampu memberikan kemudahan kepada pengguna dalam melakukan pencarian informasi. Berdasarkan penelitian tersebut, penggunaan pencarian berbasis teknologi semantik tepat untuk mengatasi kelemahan seperti pada sistem yang dikembangkan [2].

IJCCS Vol. 10, No. 1, January 2016: 23 - 34 
Kebutuhan lain para pendaki gunung yaitu informasi jalur pendakian dalam bentuk peta. Penyajian informasi dalam bentuk peta sangat berguna bagi pendaki untuk dapat melihat visualisasi entitas geografis dari jalur pendakian yang akan dilalui, sehingga memungkinkan pendaki untuk dapat menganalisa dan memperhitungkan banyak hal, seperti: waktu pendakian, lokasi mendirikan tenda, lokasi bermalam dan lokasi sumber air.

Sistem pemandu pendakian yang dikembangkan [2] mampu menyajikan informasi peta. Namun, peta yang disajikan masih berupa peta cetak berbentuk file citra kompresi (JPEG). Salah satu layanan yang dapat di manfaatkan untuk menyajikan peta interaktif yaitu Google Maps. Layanan Google Maps sangat mampu menyajikan peta interaktif yang akurat, akan tetapi aplikasi tersebut tidak menyediakan informasi yang khusus untuk pendakian gunung.

Penelitian ini sejalan dengan penelitian [2] yaitu berusaha untuk memberikan solusi untuk permasalahan pencarian informasi yang dihadapi pendaki, namun dengan menggunakan pendekatan yang berbeda. Penelitian ini berusaha mengembangkan sebuah sistem pencarian informasi jalur pendakian gunung berbasis ontologi semantik dengan menggabungkan kelebihan dari penelitian [5],[6],[7],[8]. Kemampuan pencarian yang dikembangkan yaitu mampu untuk memahami input bahasa alami dan mampu menggunakan pemahaman untuk mencari dan menghasilkan informasi dengan basis penyajian berupa peta interaktif.

\section{METODE PENELITIAN}

\subsection{Arsitektur Sistem}

Sistem yang dikembangkan pada penelitian ini merupakan sistem berbasis web. Pengguna dapat melakukan pencarian informasi jalur pendakian gunung menggunakan web browser dengan input bahasa alami yaitu bahasa Indonesia. Untuk memproses input hingga menghasilkan informasi sistem menggunakan basis pengetahuan yang direpresentasikan ke dalam dua buah ontologi (ontologi Bahasa dan ontologi Mountaineering). Data pendukung yang digunakan yaitu data geografis, data peta dan data cuaca. Sistem terbagi menjadi tiga komponen utama yaitu: Preprocessing, Pemroses Bahasa dan Penyusun Informasi. Komponen-komponen sistem dapat dilihat pada Gambar 1.

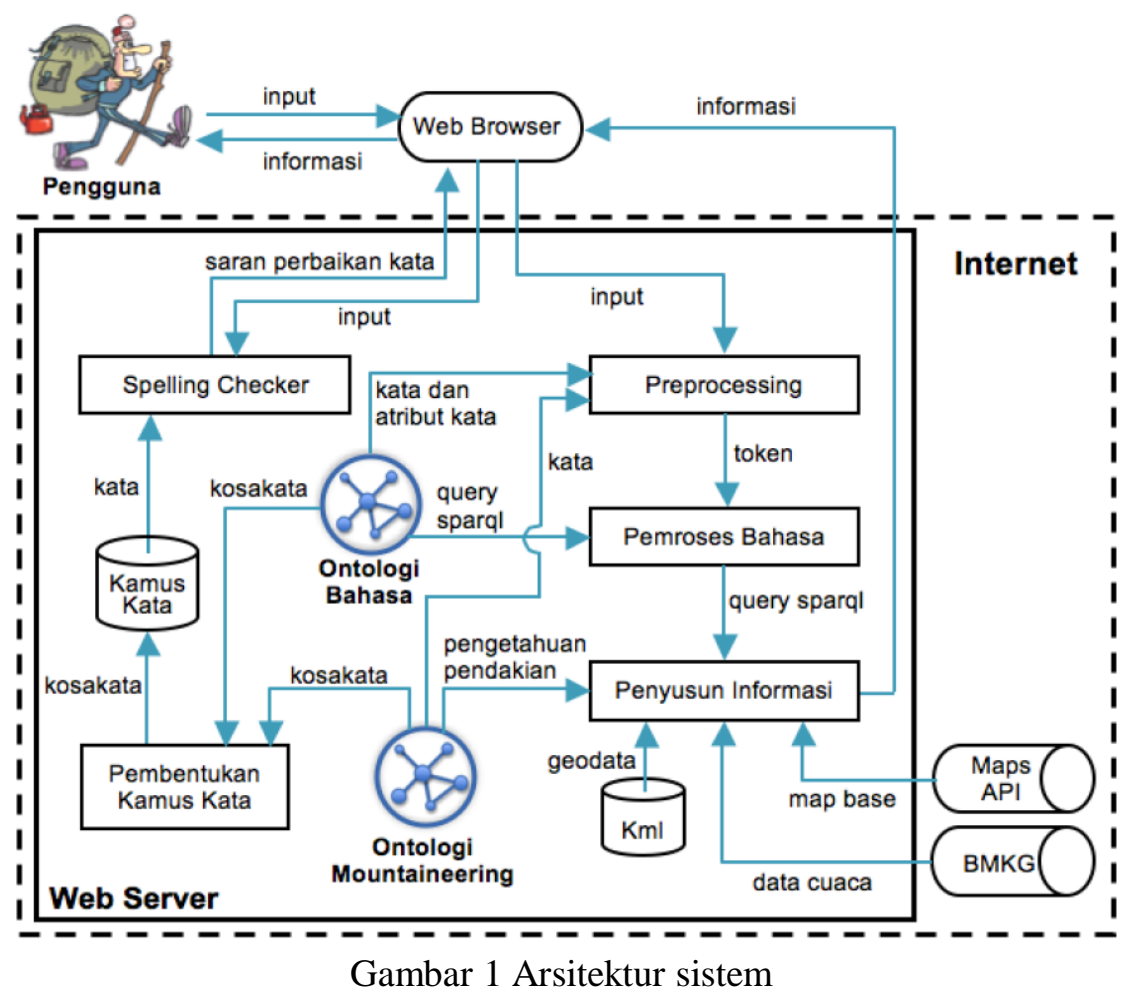




\subsection{Spelling Checker}

Komponen Spelling Checker bertujuan untuk mengurangi terjadinya kesalahan pengetikan input oleh pengguna. Selama proses input berlangsung Spelling Checker bertugas mendeteksi dan melakukan pengecekan dengan membandingkan tiap kata input dengan kata yang ada pada kamus kata. Apabila terdapat kata yang ejaannya berbeda maka komponen Spelling Checker akan mengirimkan sugestion (saran) perbaikan kata. Penelitian ini menggunakan Library Jazzy Spellchecker yang dikembangkan oleh [9] untuk Spelling Checker. Ilustrasi proses Spelling Checker disajikan pada Gambar 2.

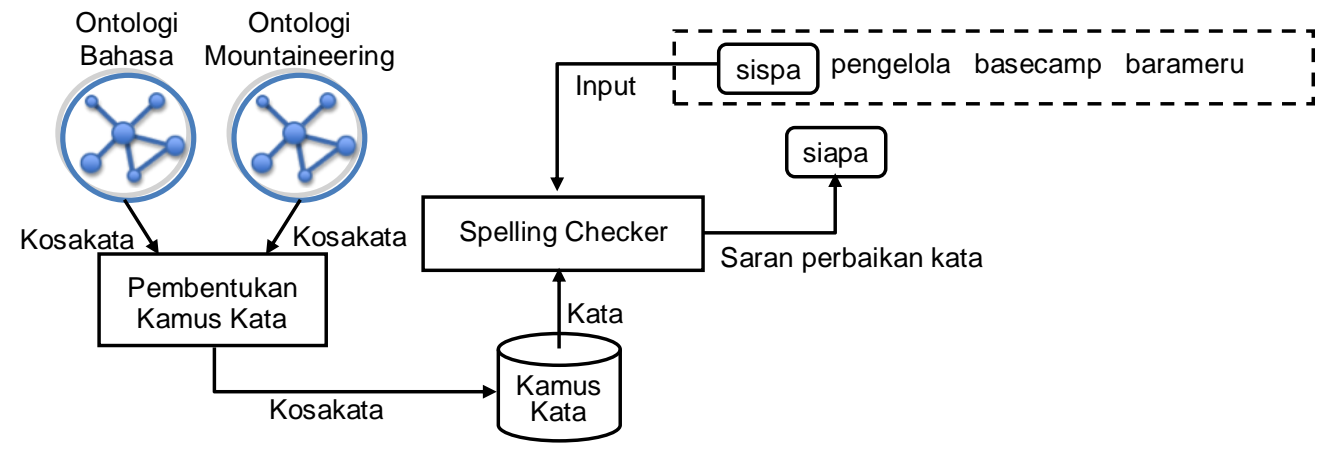

Gambar 2 Ilustrasi proses Spelling Checker

\subsection{Prepocessing}

Input yang telah di-submit pengguna diterima oleh komponen Preprocessing. Preprocessing bertugas melakukan validasi dan membentuk input menjadi urutan kata. Proses validasi dilakukan dengan mengecek setiap kata input dengan kata yang terdapat di dalam ontologi (ontologi Bahasa dan ontologi Mountaineering). Input dinyatakan valid apabila setiap kata pada input dapat dikenali (ada di dalam ontologi). Setelah input dinyatakan valid, input akan dibentuk menjadi urutan kata. Ilustrasi dari komponen Preprocessing disajikan pada Gambar 3. Proses pembentukan input menjadi urutan kata juga melibatkan pengambilan atribut tiap kata dari ontologi (ontologi Bahasa). Atribut tersebut yaitu Atribut Sintaksis yang digunakan untuk proses pengecekan sintaksis, Atribut Semantik yang digunakan untuk pengecekan semantik dan Atribut Nilai Semantik yang digunakan untuk menghasilkan query SPARQL.

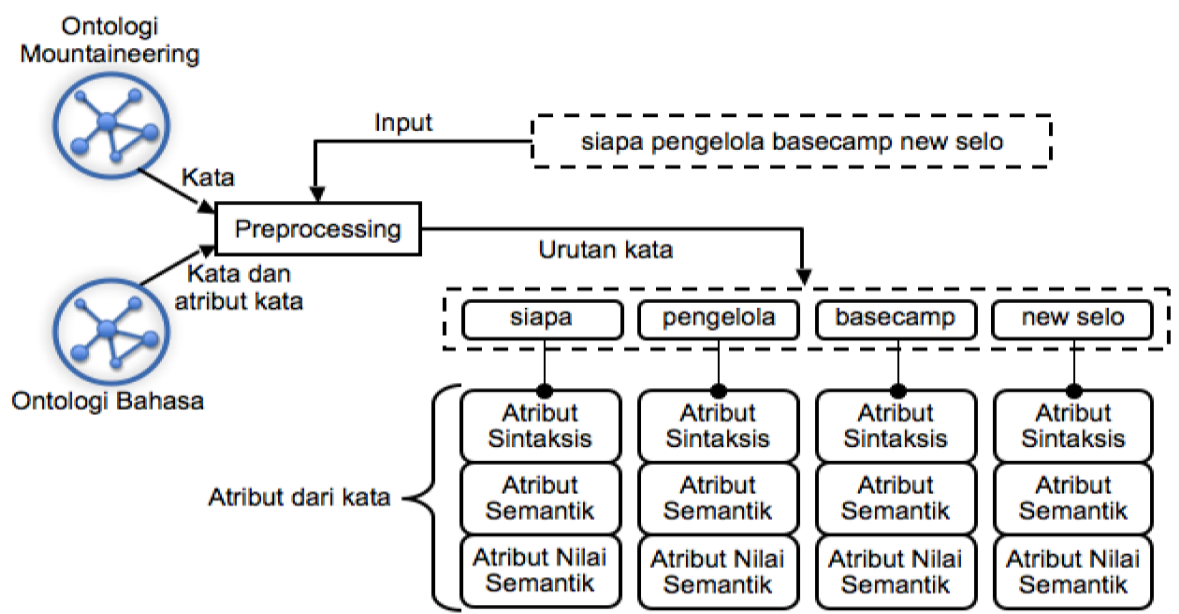

Gambar 3 Ilustrasi Prepocessing

\subsection{Pemroses Bahasa}

Tugas dari komponen Pemroses Bahasa yaitu memproses urutan kata hasil Preprocessing untuk dipahami. Proses pemahaman didasarkan pada pengecekan urutan kata secara sintaksis dan semantik menggunakan aturan tata bahasa Indonesia yang dikemukakan [10]. Pemroses 
Bahasa terdiri sub-komponen Syntax Checker, Semantic Analyzer dan Query Generator. Ilustrasi dari komponen Pemroses Bahasa dapat dilihat pada Gambar 4.

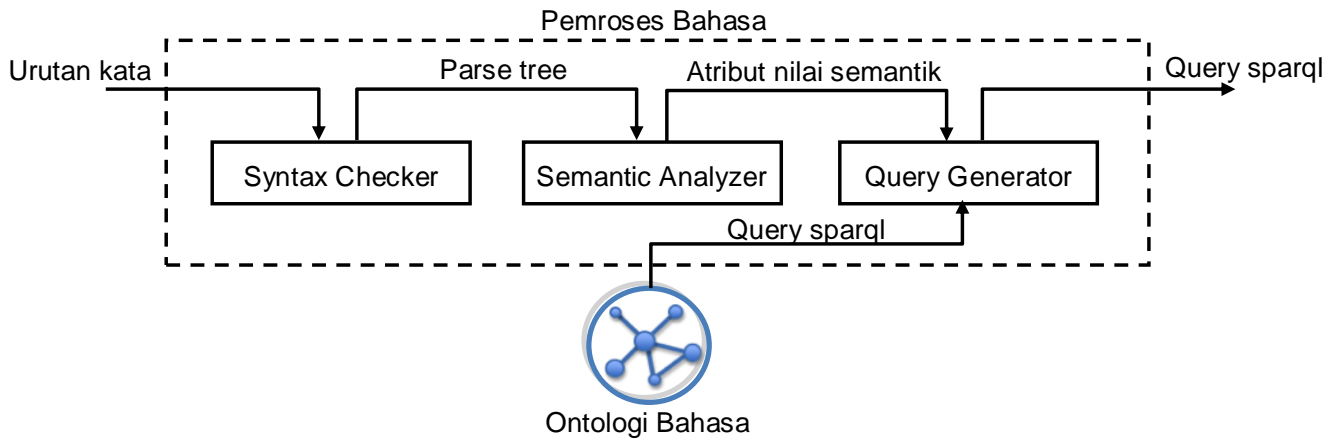

Gambar 4 Ilustrasi komponen Pemroses Bahasa

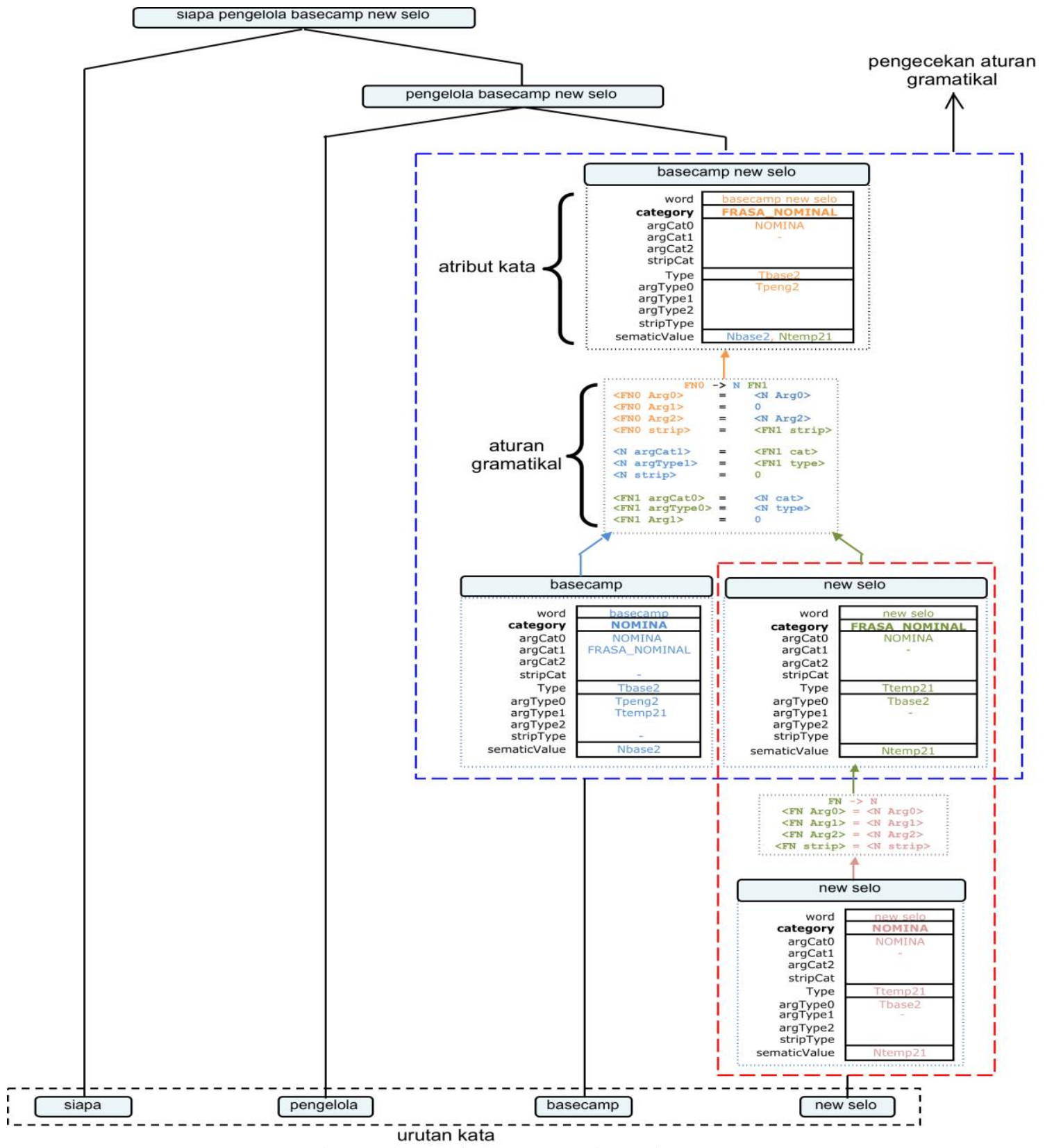

Gambar 5 Ilustrasi proses pembentukan Parse Tree 
Syntax Checker bertugas melakukan pengecekan sintaksis dengan cara mem-parsing urutan kata ke dalam parse tree. Proses pembentukan parse tree dilakukan dengan mencocokan Atribut Sintaksis dari tiap kata. Semantic Analyzer bertugas melakukan pengecekan semantik dengan cara menelusuri node-node pembentuk parse tree kemudian mencocokan atribut semantik dari tiap node. Query Generator bertugas mengubah Atribut Nilai Semantik yang dihasilkan oleh Semantic Analyzer menjadi statement-statement dalam bentuk query SPARQL. Ilustrasi pembentukan parse tree dapat dilihat pada Gambar 5. Ilustrasi pembentukan query SPARQL dapat dilihat pada Gambar 6.

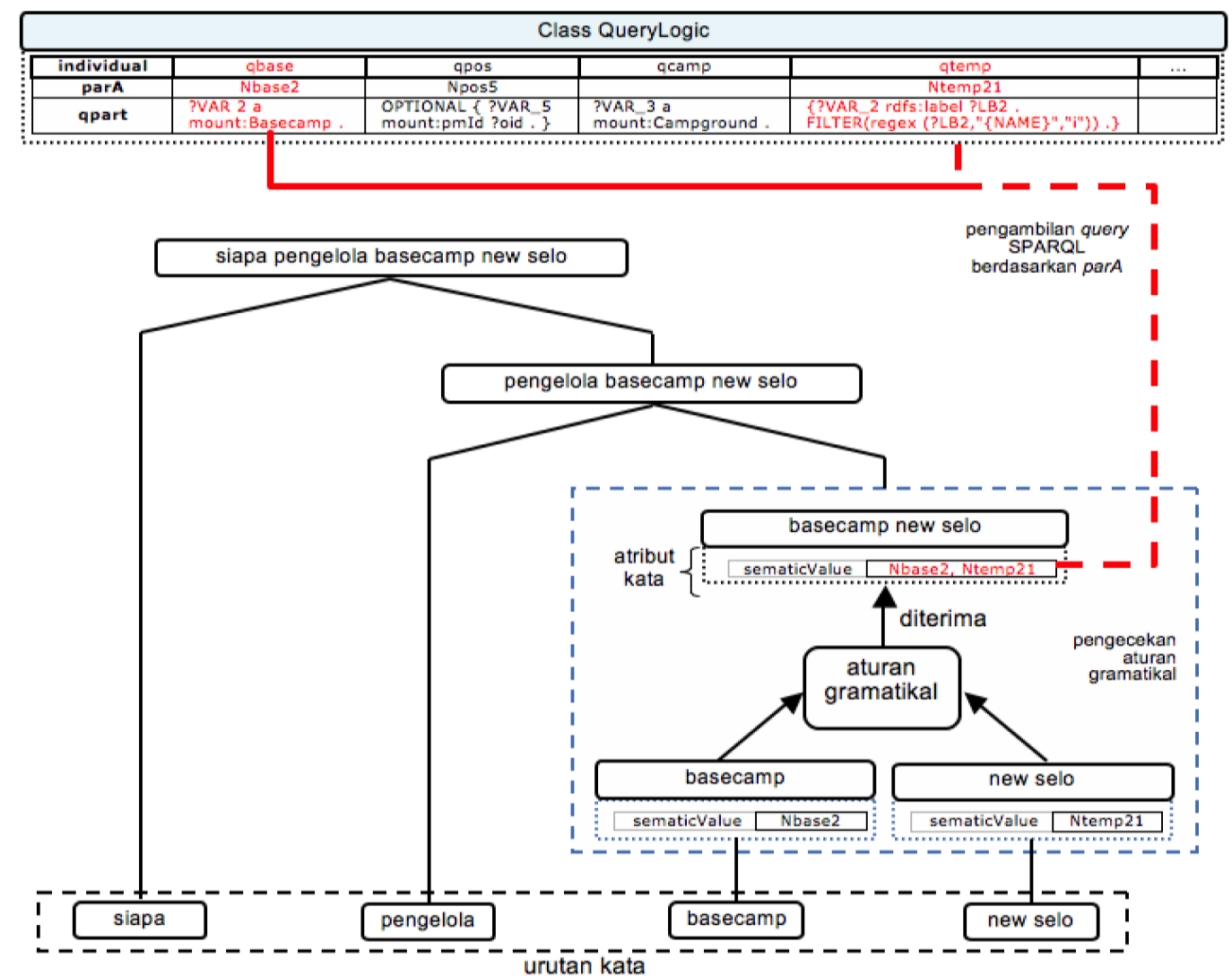

Gambar 6 Ilustrasi pembentukan query SPARQL

\subsection{Penyusun Informasi}

Komponen Penyusun Informasi bertugas mencari, menyusun dan menyajikan informasi. Penyusun Informasi terdiri dari sub-komponen Resource Retriever, KML Parser dan Respond Generator. Ilustrasi komponen Penyusun Informasi disajikan pada Gambar 7.

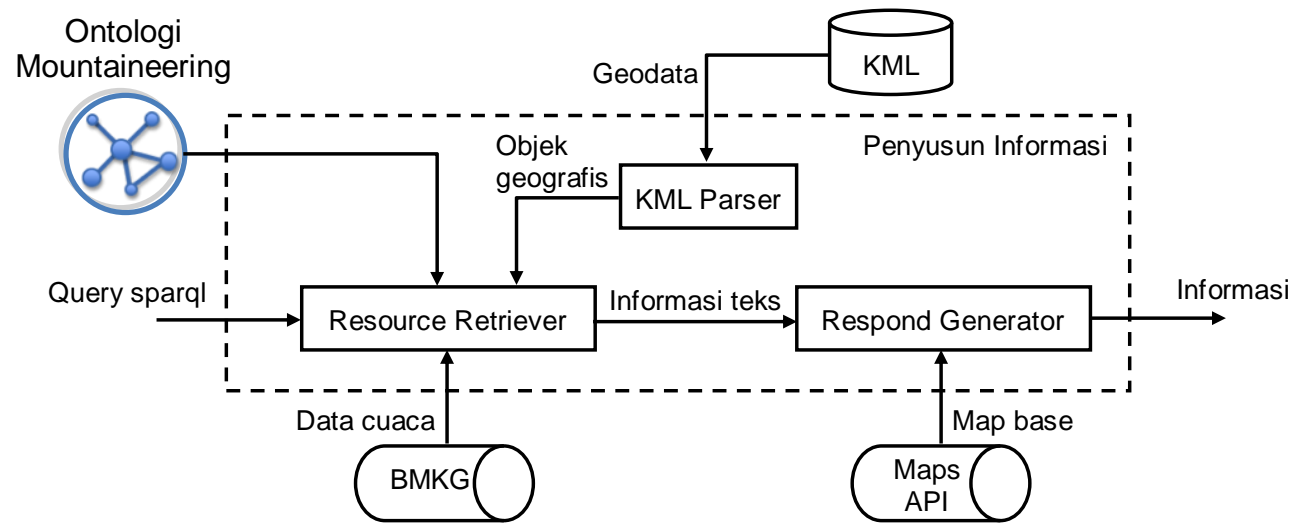

Gambar 7 Ilustrasi komponen Penyusun Informasi 
Resource Retriever bertugas melakukan proses pencarian informasi dengan mengeksekusi query SPARQL yang dihasilkan oleh Pemroses Bahasa. Resource Retriever juga bertugas mengumpulkan informasi pendukung, yaitu informasi cuaca dari web service milik BMKG dan informasi geografis yang diambil dari berkas KML. KML Parser bertugas mem-parsing informasi dari dalam berkas KML. Library KML parser yang digunakan pada penelitiain ini yaitu geoxml3 yang dikembangkan oleh [11]. Respond Generator bertugas menyajikan informasi, pesan kesalahan dan memanggil peta dari layanan Google Maps API.

\section{HASIL DAN PEMBAHASAN}

Sistem telah berhasil diimplementasikan dan untuk melihat kemampuan sistem digunakan input yang telah dipilih. Input yang digunakan untuk melihat kemampuan sistem dapat dilihat pada Tabel 1.

Tabel 1 Input yang dipilih untuk melihat kemampuan sistem

\begin{tabular}{|c|c|c|}
\hline No & Input & Keterangan \\
\hline$a 1$ & ciapa jang mengelkola basecamp barameru & $\begin{array}{l}\text { input untuk pengecekan kesalahan pengetikan } \\
\text { kata }\end{array}$ \\
\hline$c 1$ & jalur pendakian merapi & input untuk melihat penggunaan thesaurus kata \\
\hline$d 1$ & jalur pendakian selo letaknya dimana & \multirow{2}{*}{$\begin{array}{l}\text { input untuk melihat kemampuan pemahaman } \\
\text { kalimat yang berbeda secara sintaksis namun } \\
\text { memiliki makna yang sama }\end{array}$} \\
\hline$d 2$ & dimana lokasi jalur selo & \\
\hline$h 1$ & $\begin{array}{l}\text { apa saja basecamp yang terdapat di jalur } \\
\text { pendakian selo yang berlokasi di gunung } \\
\text { yang terletak di jawa tengah }\end{array}$ & $\begin{array}{l}\text { input untuk pemahaman kalimat majemuk } \\
\text { bertingkat yang akan salah apabila hanya } \\
\text { didasarkan pada analisis sintaksis saja }\end{array}$ \\
\hline$i 1$ & letaknya dimana gunung merapi & input untuk mendeteksi kesalahan sintaksis \\
\hline$i 2$ & siapa merapi & input untuk mendeteksi kesalahan semantik \\
\hline$i 3$ & apa saja basecamp di gunung & $\begin{array}{l}\text { input untuk mendeteksi penyusun kalimat yang } \\
\text { tidak lengkap }\end{array}$ \\
\hline
\end{tabular}

\subsection{Fitur Spelling Checker}

Misalkan sistem diberikan input pada Tabel 1 nomor al "ciapa jang mengelkola basecamp barameru". Tampilan penyajian saran kata-kata perbaikan selama proses input dapat dilihat pada Gambar 8.

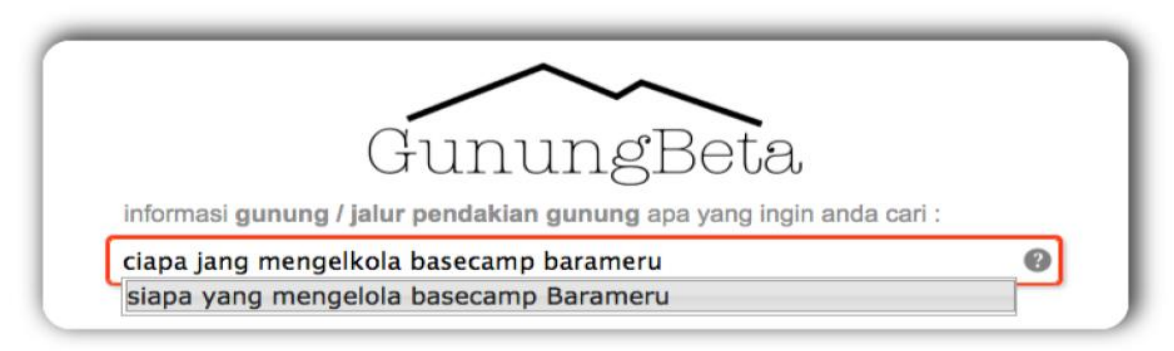

Gambar 8. Tampilan fitur Spelling Checker

Spelling Checker tidak dapat memberikan saran perbaikan kata apabila kata-kata yang diinput oleh pengguna tidak dikenali oleh sistem.

\subsection{Kemampuan menggunakan thesaurus dalam proses pencarian}

Sistem memiliki kemampuan menggunakan thesaurus sehingga pengguna tidak perlu melakukan pencarian berulang-ulang untuk mencari informasi yang saling memiliki keterkaitan berdasarkan letak/lokasi suatu objek dan keterkaitan berdasarkan makna kata. Untuk melihat kemampuan sistem menggunakan thesaurus dilakukan dengan input nomor $c 1$ pada Tabel 1 yang dapat dilihat pada Gambar 9. 


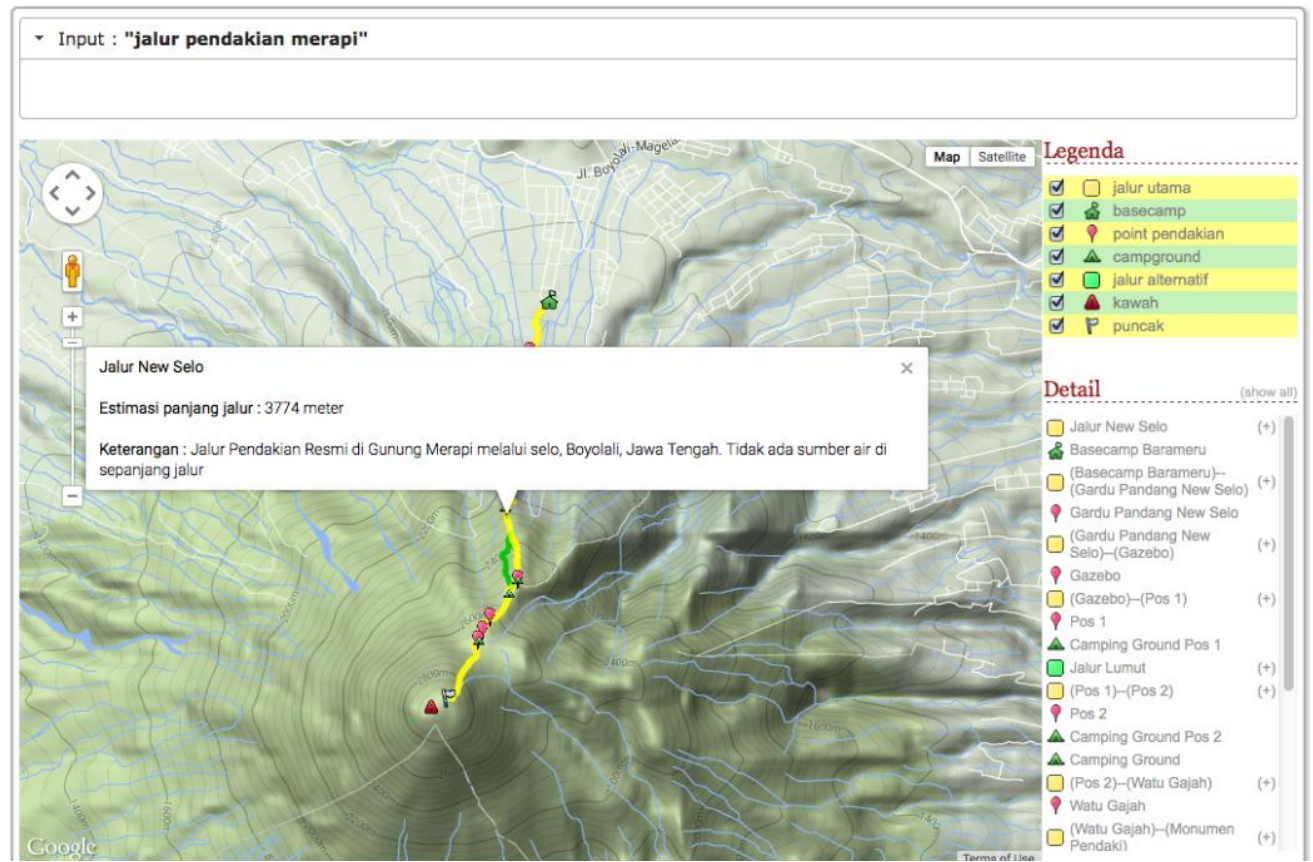

Gambar 9. Hasil pencarian dengan kemampuan thesaurus

\subsection{Kemampuan memahami input bahasa alami}

Kemampuan sistem dalam memahami input bahasa alami mengacu kepada dua hal, yaitu analisis struktur luar (surface structure) berhubungan dengan kemampuan memahami input secara sintaksis dan analisis struktur dalam (deep structure) berhubungan dengan kemampuan memahami input secara semantik.

Sistem membedakan kalimat dari satuan kata yang lain menggunakan kata tanya untuk mendeskripsikan kalimat tanya dan kata perintah untuk mendeskripsikan kalimat perintah. Kata tanya yang digunakan yaitu: "siapa", "berapa", "dimana" dan "apa". Kata perintah yang digunakan pada penelitan ini yaitu: "tampilkan".

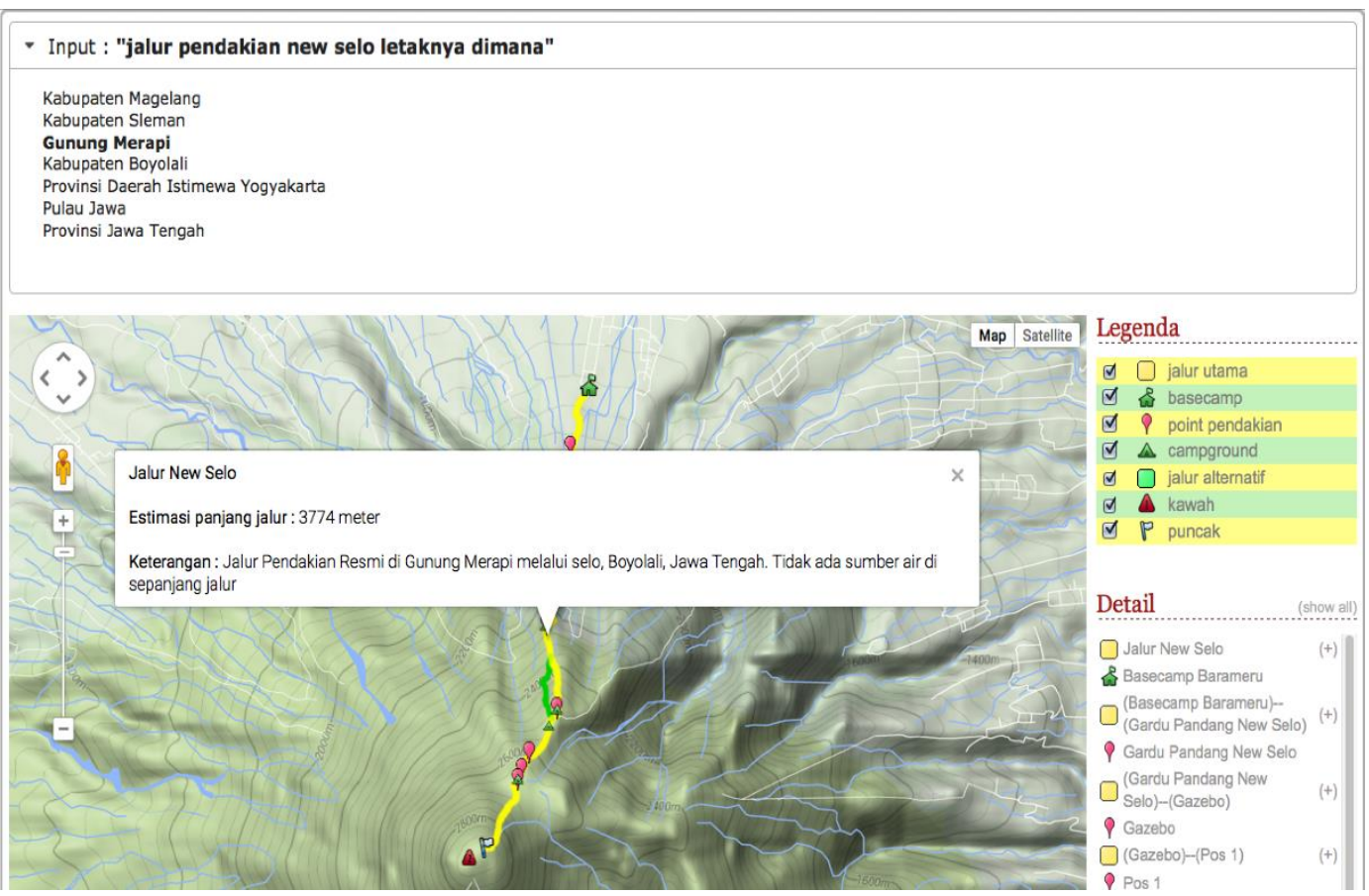

Gambar 10 Cuplikan hasil pencarian untuk kalimat berpola S-P 
Kemampuan sistem memahami input berupa kalimat dengan pola sintaksis yang berbeda namun memiliki makna yang sama ditunjukkan dengan menggunakan input pada Tabel 1 nomor d1 "jalur pendakian new selo letaknya dimana" yang merupakan kalimat tunggal berpola S-P dan input pada Tabel 1 nomor $d 2$ "dimana lokasi jalur new selo" yang berpola P-S. Cuplikan untuk kedua input tersebut dapat dilihat pada Gambar 10 dan Gambar 11.

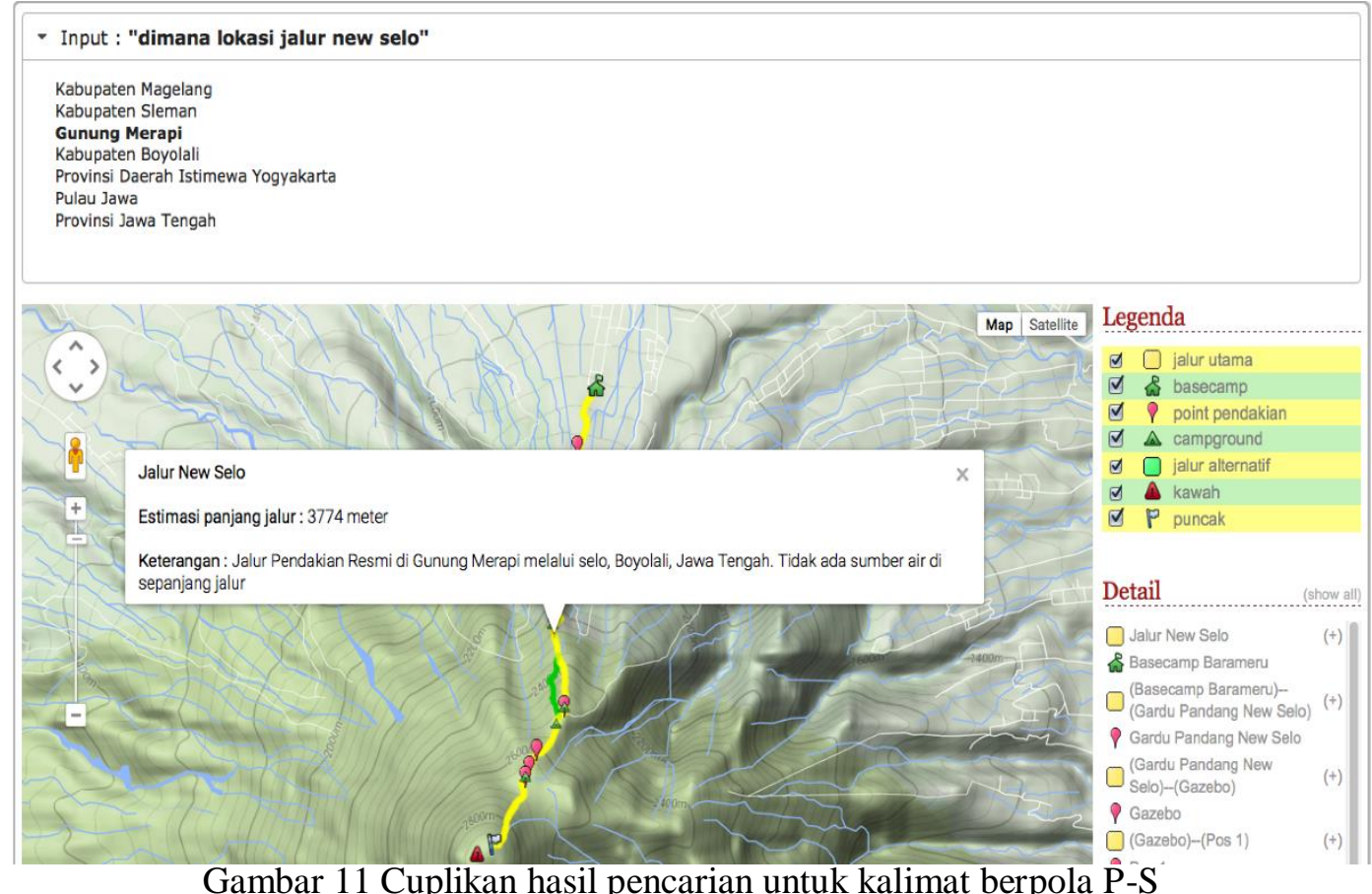

Kemampuan sistem dalam memahami input berupa kalimat mejemuk bertingkat yang jika dipahami dengan menggunakan analisis sintaksis saja akan menghasilkan informasi semantik yang salah ditunjukkan dengan menggunakan input pada Tabel 1 nomor $h l$ "apa saja basecamp yang terdapat di jalur pendakian selo yang berlokasi di gunung yang terletak di jawa tengah", cuplikan hasil pencarian dapat dilihat pada Gambar 12.

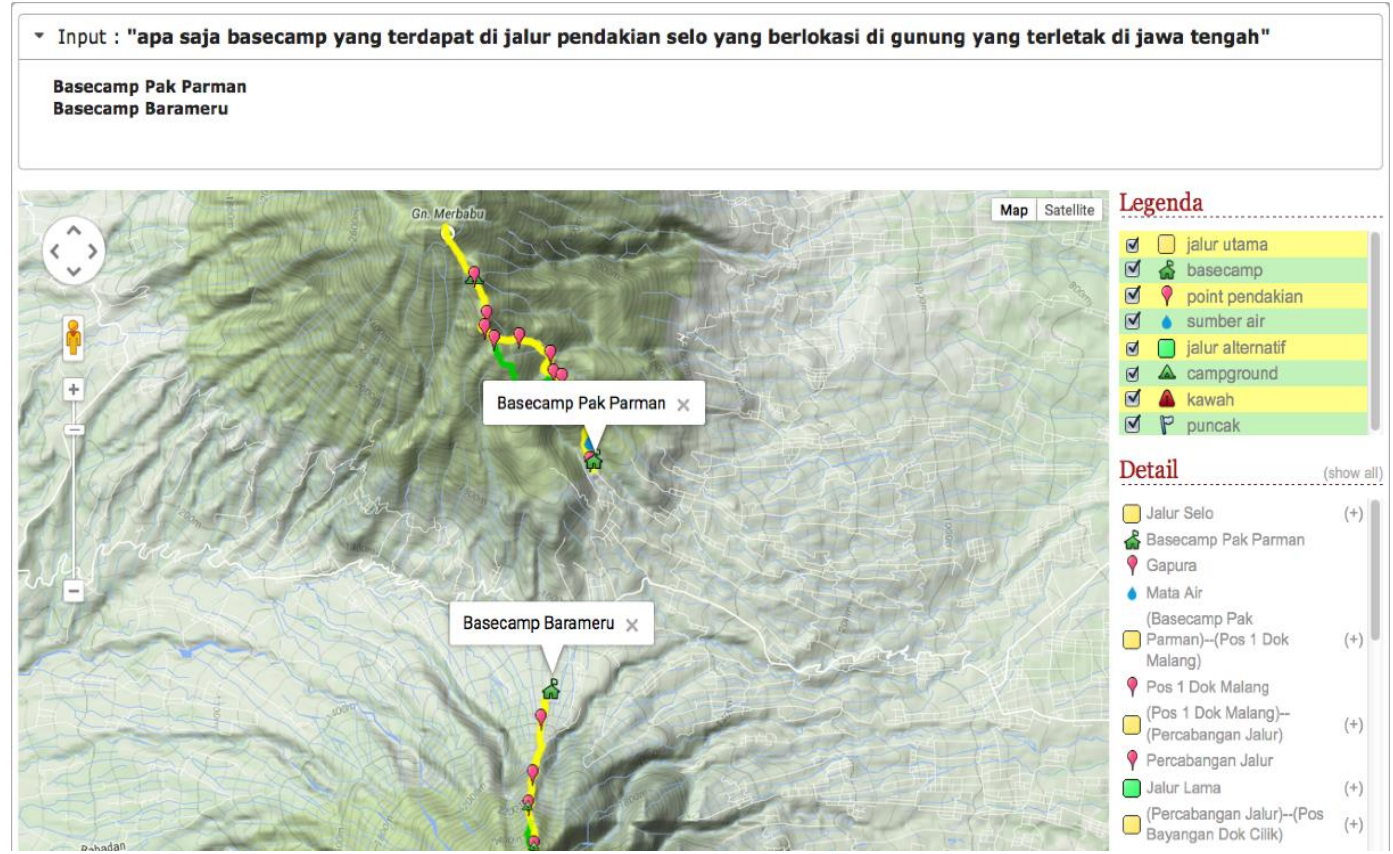

Gambar 12. Contoh hasil pencarian untuk kalimat majemuk bertingkat 


\subsection{Kemampuan mendeteksi input yang tidak sesuai dengan kaidah bahasa Indonesia}

Kemampuan sistem mendeteksi kesalahan input dibagi kedalam tiga kategori, yaitu kemampuan mendeteksi input yang salah secara sintaksis, kemampuan untuk mendeteksi input dapat diterima secara sintaksis namun tidak dapat diterima secara semantik dan kemampuan untuk mendeteksi input yang penyusun kalimatnya tidak lengkap.

Kemampuan sistem untuk mendeteksi kesalahan sintaksis ditunjukkan menggunakan input pada Tabel 1 nomor i-1 "letaknya dimana gunung merapi" yang dapat dilihat pada Gambar 13. Kemampuan sistem untuk mendeteksi input yang dapat diterima secara sintaksis namun tidak dapat diterima secara semantik ditunjukkan menggunakan input pada Tabel 1 nomor i-2 "siapa merapi" yang dapat dilihat pada Gambar 14. Kemampuan sistem untuk mendeteksi input yang penyusun kalimatnya tidak lengkap ditunjukkan menggunakan input pada Tabel 1 nomor $i$-3 "apa saja basecamp yang di gunung" dapat dilihat pada Gambar 15.

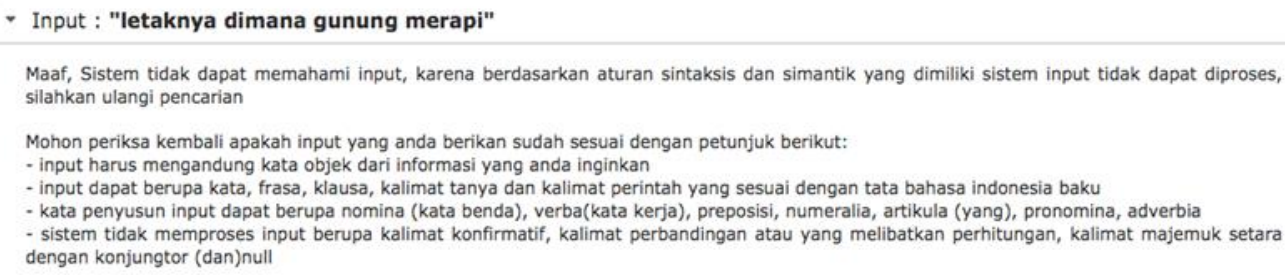

Gambar 13 Cuplikan pesan untuk input yang salah secara sintaksis

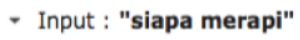

Gambar 14 Cuplikan pesan untuk input yang salah secara semantik

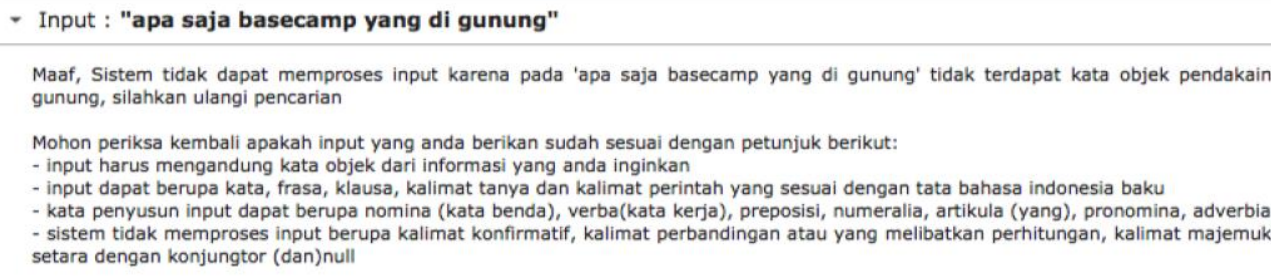

Gambar 15 Cuplikan pesan untuk input kalimat yang kata penyusunnya tidak lengkap

\section{KESIMPULAN}

1 Penggunaan ontologi Bahasa untuk merepresentasikan pengetahuan di bidang linguistik yang meliputi pengetahuan tentang kata, hubungan kata, persamaan kata (thesaurus), kategori kata, fungsi sintaksis dan perilaku semantik memungkinkan sistem untuk menggunakan aturan-aturan tata bahasa Indonesia baku dalam memahami input bahasa alami baik secara sintaksis maupun semantik. Selain itu dengan penggunaan ontologi Bahasa sistem juga mampu mendeteksi input yang tidak sesuai dengan kaidah tata bahasa Indonesia.

2 Penggunaan KML berfungsi untuk mendeskripsikan data-data keruangan (spasial) yang dapat diintegrasikan dengan pengetahuan yang ada pada ontologi mountaineering, sehingga sistem mampu menyajikan hasil pencarian ke dalam bentuk peta interaktif.

3 Hasil pengujian secara kuantitatif menunjukkan bahwa sistem mampu memahami input yang diambil secara acak dari responden sebesar 69\%. Meskipun demikian titik berat 
pemrosesan bahasa dengan penggunaan ontologi Bahasa yang dikembangkan pada penelitian ini bukan pada banyaknya jumlah input yang mampu diproses, tapi pada kualitas pemrosesan bahasa.

\section{SARAN}

1 Ketidakmampuan sistem dalam memprosess input disebabkan karena kurangnya pengetahuan dan aturan gramatikal yang dimiliki sistem. Penelitian selanjutnya diharapkan dapat mengembangkan pengetahuan-pengetahuan, yaitu :

2 Ontologi Bahasa untuk satuan bahasa yang mengandung unsur adjektiva, adverbia dan konjungtor "dan". Pengembangan ontologi Bahasa sebaiknya melibatkan orang-orang yang ahli di bidang linguistik.

3 Ontologi Mountaineering untuk pengetahuan tentang perlengkapan pendakian dan transportasi kendaraan menuju basecamp.

4 Dapat ditambahkan fasilitas konversi data dari format KML ke dalam format GPX (GPS Exchange Format) sehingga data-data spasial dapat diunduh dan digunakan ke dalam alat GPS.

\section{DAFTAR PUSTAKA}

[1] Sastha, H. B., 2007, Mountain Climbing for Everybody: Panduan Mendaki Gunung, Hikmah (PT Mizan Publika), Jakarta.

[2] Handaya, W. B. T. dan Lestari, D. P., 2011, Implementasi Sistem Pemandu Pendakian Gunung, Seminar Nasional Teknologi Informasi \& Komunikasi Terapan 2011 (Semantik 2011), Semarang, 16 April 2011, Hal.1-6.

[3] Azhari dan Sholichah, M., 2006, Model Ontologi untuk Informasi Jadwal Penerbangan Menggunakan Protégé, Jurnal informatika, No.1, Vol.7, Hal.J67-J76.

[4] Rahutomo, F., 2009, Penerapan Algoritma Weighted Tree Similarity untuk Pencarian Semantik Wikipedia, Tesis, Jurusan Teknik Informatika, Fakultas Teknologi Informasi, Institut Teknologi Sepuluh Nopember, Surabaya.

[5] Nurkhamid, M., 2009, Aplikasi Bibliografi Perpustakaan Berbasis Teknologi Web Semantik, Tesis, Program Studi S2 Ilmu Komputer, Fakultas Matematika dan Ilmu Pengetahuan Alam, Universitas Gadjah Mada, Yogyakarta.

[6] Bendi, R. J. K., 2010, Sistem Question Answering Sederhana Berbasis Ontologi Sebagai Aplikasi Web Semantik, Tesis, Program Studi S2 Ilmu Komputer, Fakultas Matematika dan Ilmu Pengetahuan Alam, Universitas Gadjah Mada, Yogyakarta.

[7] Andri, 2011, Rancang Bangun Online Public Access Catalaog (OPAC) Berbasis Web Sematik, Tesis, Program Studi S2 Ilmu Komputer, Fakultas Matematika dan Ilmu Pengetahuan Alam, Universitas Gadjah Mada, Yogyakarta.

[8] Suryawan, I. W. D., 2013, Sistem Question Answering Menggunakan Pendekatan Berbasis Pengetahuan, Tesis, Program Studi S2 Ilmu Komputer, Fakultas Matematika dan Ilmu Pengetahuan Alam, Universitas Gadjah Mada, Yogyakarta.

[9] Idzelis, M., 2005, Jazzy: The java open soure spell checker, http://jazzy.sourceforge.net/, diakses 4 November 2013. 
[10] Alwi, H., Dardjowidjojo, S., Lapoliwa, H. dan Moeliono, A. M., 2003, Tata Bahasa Baku Bahasa Indonesia, Edisi Ketiga, PT Balai Pustaka (Persero), Jakarta.

[11] Udell, S., 2012, Geoxml3: KML processor for the Google Maps JavaScript API V3, http://code.google.com/p/geoxml3/, diakses 4 November 2012. 